\title{
APAKAH OPEC MERUPAKAN KARTEL?: PENDEKATAN KAUSALITAS GRANGER DALAM KERANGKA VECTOR AUTOREGRESSIVE
}

\author{
Andryan Setyadharma \\ Magister Sains IESP \\ Sekolah Pascasarjana Universitas Gadjah Mada
}

\begin{abstract}
One would believe that The Organization of Petroleum Exporting Countries (OPEC) is certainly a cartel which curbs production in order to raise the price of its product as well as to share the market among its members. Did energy shock of the 1970's engineered by an effective cartel of OPEC members acting to share the market by controlling output and influencing market prices? One would also expect OPEC's production to significantly affect the market price of oil as the organization is often accused of curbing production in order to raise prices. This paper tries to determine whether OPEC has the power of affecting the market price of oil and or vice versa. This study uses the Toda and Yamamoto (1995) procedure for testing for Granger non-causality in Vector Autoregressive (VAR) models that involves variables that are integrated of an arbitrary order and that are possibly cointegrated. The results indicate that there is no statistically significant causal relationship between real crude oil price and OPEC production in either direction for full sample period 1974 - 2005. Instead, we find that real crude oil price Granger cause OPEC production in 2 different sub samples period, but not in other direction. As overall we reject cartel hypothesis for OPEC as a whole.
\end{abstract}

Keywords: OPEC, Granger Causality Test, VAR, Toda and Yamamoto

\section{PENDAHULUAN}

Semenjak OPEC dibentuk pada tahun 1960, organisasi yang beranggotakan 11 negara ini (Algeria, Arab Saudi, Indonesia, Iran, Irak, Kuwait, Libya, Nigeria, Qatar, Uni Emirat Arab, dan Venezuela) telah dipersalahkan atas sejumlah kejadian, terutama krisis energi pada tahun 1970an yang puncaknya pada tahun 1973-1974 terjadi peningkatan empat kali lipat harga minyak dunia yang menurut banyak pihak disebabkan oleh perilaku kolusif dari para anggota OPEC. Setelah tahun 1982, OPEC menerapkan rasio output bagi para anggotanya dan bersikap sebagaimana perilaku kartel pada umumnya meskipun tanpa ada perlengkapan untuk deteksi maupun hukuman. Mulai tahun 1982, produksi OPEC disebut dengan era rasio output (Gulen, 1996). Dari tahun 1982 sampai tahun 1985 OPEC berusaha mengatur kuota produksi yang cukup rendah untuk menstabilkan harga. Usaha-usaha ini mengalami kegagalan yang berulang terus karena banyak anggota OPEC berproduksi di luar kuota yang telah ditetapkan.

Hampir selama periode ini Arab Saudi berperan sebagai produsen penyeimbang (swing producer) yang memotong produksi dalam negerinya untuk menahan kejatuhan harga. Pada Agustus 1985, Arab Saudi tidak mau berperan sebagai penyeimbang lagi. Mereka akhirnya menetapkan harga minyak mereka pada harga pasar minyak mentah dan pada awal 1986 meningkatkan produksi dari 2 juta barel per hari menjadi 5 juta barel per hari. Harga minyak mentah jatuh pada kisaran $\$ 10$ per barel pada pertengahan 1986 walaupun pada akhir tahun 1986 sempat berada pada kisaran $\$ 14$. Secara umum, pada tahun 1985-1986 harga minyak jatuh dari sekitar $\$ 28$ menjadi di bawah $\$ 12$ per barel (harga nominal). Dari tahun 1980 sampai 1986 
produksi Non-OPEC meningkat menjadi 10 juta barel per hari. Pada tahun-tahun tersebut, OPEC dihadapkan pada permintaan yang rendah dan suplai yang tinggi dari luar organisasi.

Harga kembali pada kisaran \$17 sampai \$19 per barel pada tahun 1987 dan kembali melonjak pada harga $\$ 30$ setelah invasi Irak ke Kuwait. Pada akhir tahun 1993 harga kembali jatuh pada kisaran di bawah $\$ 15$ per barel meskipun ada pertemuan maraton OPEC. Ketika terjadi krisis ekonomi di Asia pada pertengahan tahun 1997, harga berkisar pada \$17 dan turun tajam pada akhir tahun 1998 yang sempat menembus angka di bawah $\$ 10$ per barel. Harga sempat kembali meningkat dan mencapai puncaknya pada tahun 2000 pada kisaran $\$ 30$ pada harga nominal. Namun akibat serangan teroris pada bulan September 2001, perekonomian dunia melemah sehingga menyebabkan harga minyak sempat turun pada kisaran \$16 pada akhir tahun 2001. Pada tahun 2002, harga mengalami kecenderungan meningkat dan harga tertinggi yang pernah tercatat adalah pada harga $\$ 58,79$ harga nominal per barel pada September 2005. Namun bila harga-harga pada periode 1974-2005 dideflasikan, maka harga tertinggi nominal ini masih dianggap rendah bila dibandingkan dengan harga pada bulan Februari 1981 yang bila dideflasikan mencapai harga $\$ 73,98$. (lihat Gambar 1).

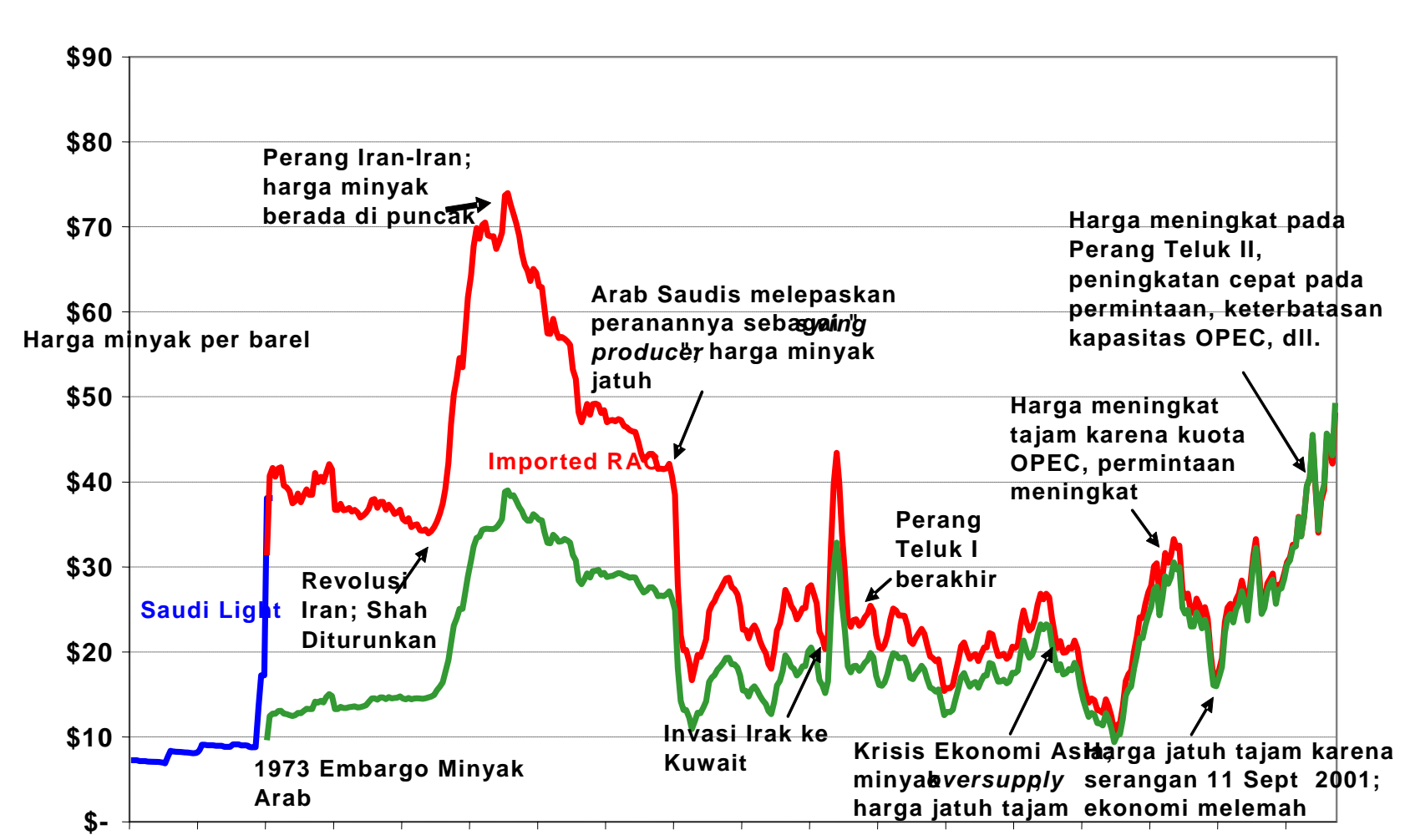

197019721974197619781980198219841986198819901992199419961998200020022004

Harga Resmi Saudi nightHarga Riï-Harga Nominal

Sumber: Energy Information Administration (2006)

Gambar 1.

Harga Minyak Dunia dan Kejadian Utama, 1970-2005

(Harga Riil disesuaikan dengan GDP deflator, 2 Q 2005 Dollar) 
Kegagalan OPEC untuk mempertahankan harga minyak dari kejatuhannya, terutama pada era rasio output, menimbulkan berbagai pertanyaan mengenai kemampuan OPEC. Apakah OPEC mampu mengatur kuota produksi di antara para anggotanya dalam usahanya mengkontrol harga pasar minyak?. Di lain pihak, pada tahun 1980 terjadi penurunan yang signifikan pada permintaan minyak oleh negara-negara industri utama, yang melakukan program penyimpanan energi dan menggantikannya dengan batu bara dan energi nuklir, dan peningkatan suplai oleh produsen Non-OPEC. Pada Gambar 2 dapat dilihat bahwa pada tahun 1980-an, terjadi kenaikan suplai oleh negara-negara Non-OPEC yang kemudian direspon oleh OPEC dengan penurunan jumlah produksi. Perilaku tersebut, terutama tanggapan dari negara-negara industri terhadap krisis energi tahun 1979-1980, dianggap sebagai perilaku kartel OPEC.

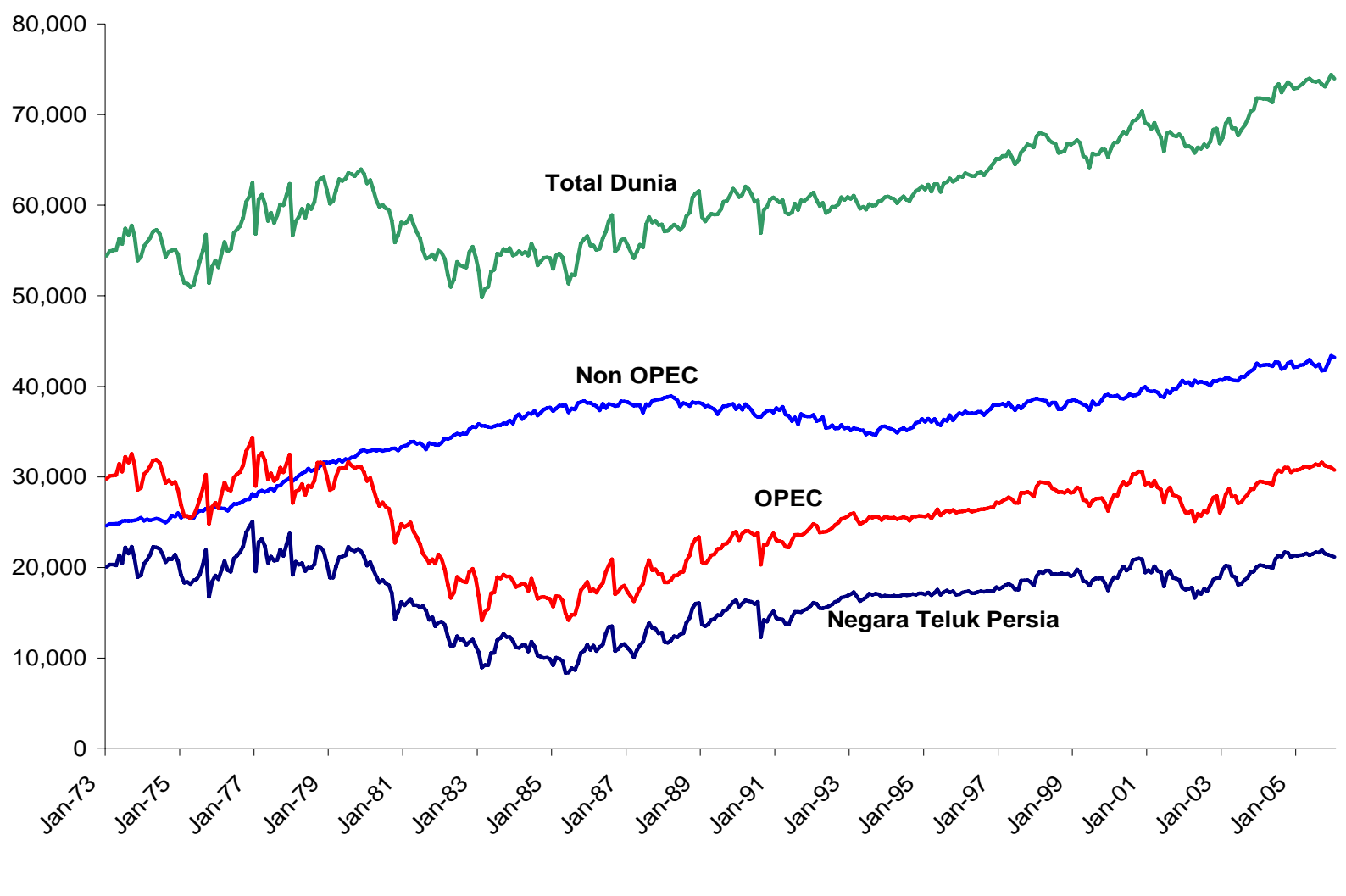

Sumber: EIA (2006)

Gambar 2.

Produksi Minyak Mentah Dunia, 1973-2005

Sementara itu, perbandingan antara produksi minyak mentah OPEC dan Non-OPEC dapat dilihat pada Gambar 3. dalam kurun waktu periode 10 tahunan, dapat dilihat bahwa rata-rata produksi OPEC sekitar 40\% dari total produksi minyak mentah dunia. Namun setelah periode 1974 - 1983, persentase produksi minyak mentah OPEC tiap periode tidak pernah melebihi periode 1974 - 1983. 


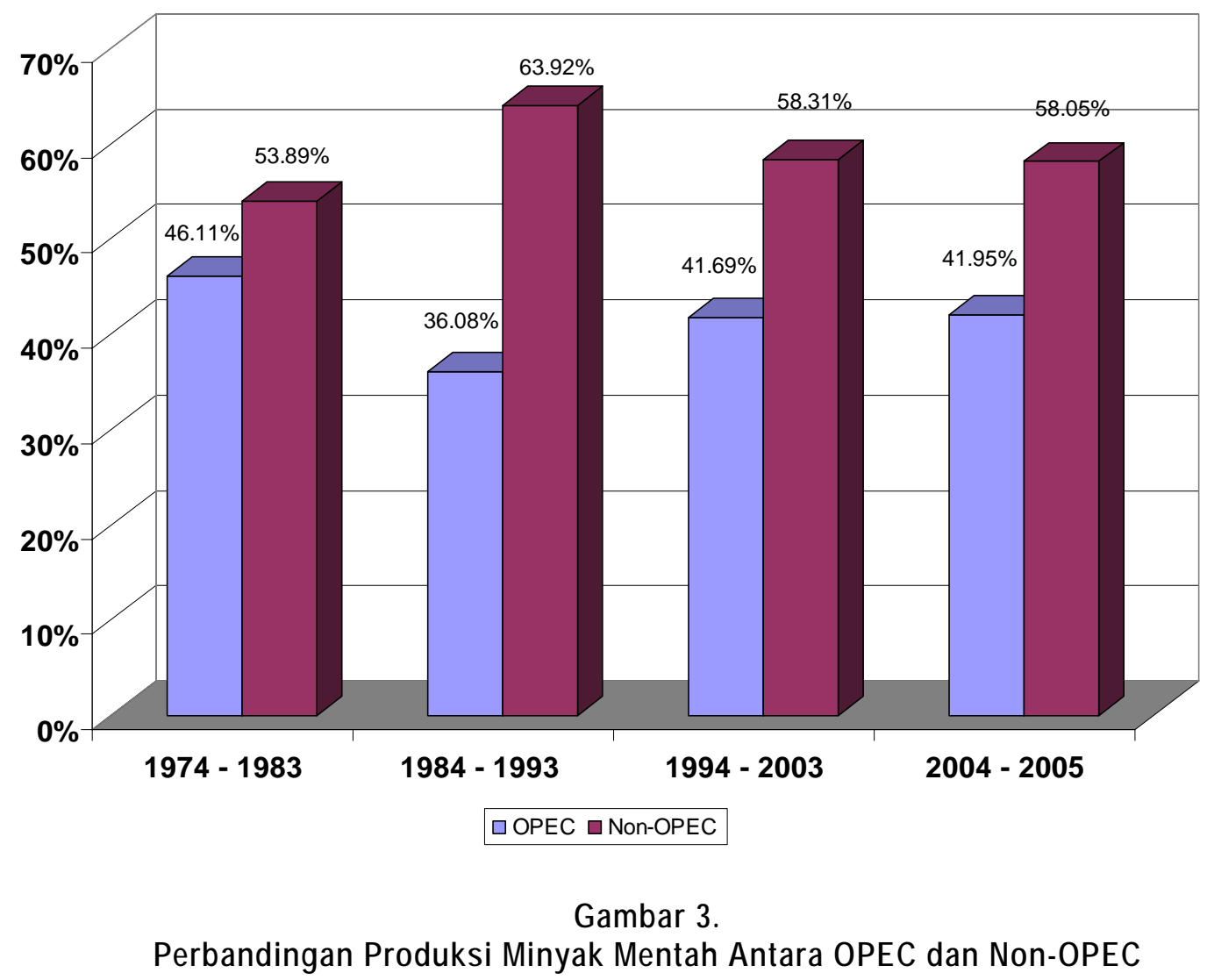

Dengan share yang cukup besar, seharusnya OPEC memiliki kemampuan dalam mengkontrol harga. Namun permasalahannya yang dihadapi adalah kecurangan anggotanya sendiri yang tidak mau mematuhi kuota yang telah ditetapkan sehingga keefektifan kartel dipertanyakan.

Studi ini akan mencoba melihat apakah OPEC berperilaku sebagai kartel yang memiliki kekuatan untuk mempengaruhi harga minyak mentah dunia dengan mengkontrol jumlah produksi minyak para anggotanya. Implikasi dari perilaku kartel akan coba diuji melalui uji kausalitas Granger (1969). Untuk menentukan jumlah lag yang optimal akan digunakan prosedur yang dikembangkan oleh Toda dan Yamamoto (1995).

\section{TINJAUAN LITERATUR}

\subsection{Penelitian Sebelumnya}

Penelitian empiris mengenai perilaku OPEC sebagai suatu organisasi dan perilaku anggota-anggotanya dimulai oleh Griffin (1985) dan dikembangkan melalui sejumlah modifikasi (lihat misalnya Loderer, 1985; Green, 1988; Dahl dan Yucel, 1991; Polasky, 1992; Jones, 1990; Griffin dan Neilson, 1994; Gulen, 1996; Alhajji dan Huettner, 2000a; Alhajji dan Huettner, 2000b; Spilimbergo, 2001; Ramcharran, 2002; Kaufmann et al., 2004; Smith, 2005)

Griffin (1985) membuat suatu model sederhana untuk menggambarkan produksi OPEC seperti berikut:

$$
Q_{i t}=\alpha_{i}^{*} Q_{o t}
$$

Di mana $Q_{i t}$ adalah jumlah minyak mentah yang diproduksi oleh negara anggota OPEC $i$ pada waktu $t, Q_{O t}$ adalah jumlah minyak mentah yang diproduksi oleh seluruh anggota OPEC dan $i$ 
adalah bagian (share) negara $i$ dari total produksi minyak OPEC di mana $0<{ }_{i}<1$. Griffin (1985) memodifikasi persamaan (1) untuk menghindari simultaneity dan untuk menjadikan produksi minyak negara $i$ sebagai fungsi dari harga minyak, seperti berikut:

$$
Q_{i t}=\alpha_{i}^{o} P_{t}^{r i} Q_{o o t}
$$

Di mana $P$ adalah harga minyak mentah riil dan $Q_{o o}$ adalah jumlah minyak mentah yang diproduksi oleh anggota OPEC selain negara i. Untuk mengestimasi persamaan (2), kedua sisi dijadikan dalam bentuk logaritma sebagai berikut:

$$
\ln Q_{i t}=\alpha_{i}+\gamma \ln P_{t}+\beta \ln Q_{o o t}+\varepsilon_{\text {it }}
$$

Di mana $\varepsilon_{i t}$ adalah error.

Griffin (1985) menggunakan estimasi ekonometri pada $\beta$ dan $\gamma$ untuk menguji hipotesis tentang perilaku OPEC. Nilai positif untuk $\gamma$ diinterpretasikan sebagai bukti dari perilaku kompetitif dan nilai negatif diinterpretasikan sebagai bukti dari perilaku perilaku non-kompetitif.

Jika OPEC mengalokasikan share pasar di antara anggota-anggotanya, namun tidak menggunakan share yang konstan, $\beta>0$. Share pasar yang konstan menunjukkan $\beta=1$. Persamaan (3) dan derivasinya diestimasi dari sampel yaang berbeda periode dan frekuensinya (Kaufmann et al., 2005). Estimasi empiris dari persamaan (3) dan turunannya memiliki banyak masalah, termasuk bias karena penghilangan variabel-variabel, ukuran sampel yang kecil, dan serial correlation (Alhajji dan Huettner, 2000a). Smith (2005) menyatakan bahwa spesifikasi Griffin dan turunanmya sangat mungkin untuk ditolak karena bentuk perilaku yang ekstrim, seperti misalnya "pembagian pasar yang konstan". Untuk perilaku yang tidak terlalu ekstrim, model tersebut memiliki kekuatan yang lemah untuk memilih di antara hipotesis yang ada untuk menunjukkan sifat dari OPEC sebagai suatu organisasi.

Griffin (1985) menggunakan periode waktu kuartalan 1971:I sampai 1983:III dalam mengestimasi persamaan (3) dan hasilnya menunjukkan $\gamma<0$ pada 5 negara anggota OPEC. Jones (1990) dengan periode waktu yang berbeda (1982:IV-1988:IV) dalam penelitiannya juga menemukan hubungan negatif, namun hanya untuk dua negara anggota OPEC. Bukti dari perlaku non-kompetitif diperkuat oleh Ramcharran (2002), yang menemukan hubungan negatif antara harga dan produksi dalam data tahunan (1973 - 1997) untuk tujuh negara anggota OPEC.

Interpretasi hubungan negatif ini dipertanyakan oleh Gulen (1996) dan Kaufmann et al. (2004), yang menemukan bahwa hubungan dari estimasi studi sebelumnya tidak terkointegrasi dan tidak "Granger cause" produksi. Tanpa kointegrasi, hubungan negatif antara produksi dan harga kemungkinan lancung (spurious) (Granger dan Newbold, 1974). Tanpa mengetahui hubungan kausal, hubungan negatif dapat diartikan bahwa OPEC mengurangi produksi untuk merespon harga atau bahwa kenaikan produksi oleh OPEC mengurangi harga.

Hasil penelitian dari Kaufmann et al. (2004), dengan menggunakan data kuartalan, 1986:III sampai 2000:III, menunjukkan bahwa terdapat hubungan yang secara statistik signifikan antara harga minyak riil, penggunaan kapasitas OPEC, kuota OPEC, derajat di mana produksi OPEC melebihi kuotanya dan stok minyak mentah OECD, di mana variabel-variabel tersebut "Granger cause" harga minyak riil namun harga minyak riil tidak "Granger cause" penggunaan kapasitas OPEC, kuota OPEC, derajat di mana produksi OPEC melebihi kuotanya dan stok minyak mentah OECD. Hasil ini menunjukkan bahwa OPEC memainkan peranan penting dalam menentukan harga minyak riil.

Sementara itu, sejumlah penelitian memberikan bukti-bukti yang menolak hipotesis kartel OPEC. Alhajji dan Huettner (2000a; 2000b) menolak hipotesis kartel bagi OPEC secara keseluruhan maupun inti dari OPEC (Arab Saudi, Kuwait, Uni Emirat Arab, dan Qatar). Lebih lanjut lagi, Alhajji dan Huettner (2000a) menyatakan bahwa Arab Saudi adalah perusahaan yang dominan dan anggota lain dari OPEC dapat dimodelkan dengan menggunakan gambaran 
alternatif, seperti misalnya model penerimaan. Smith (2005) menyimpulkan bahwa struktur pasar OPEC terletak di antara oligopoli yang non-kooperatif dan kartel, serta menyatakan bahwa OPEC bertindak seperti layaknya sindikat birokratik.

Menggunakan spesifikasi ARIMA, Loderer (1985) menemukan bahwa OPEC tidak mempengaruhi harga minyak pada periode 1974-1980, namun mampu mempengaruhi harga minyak pada periode 1981 dan 1983. Hasil penelitiannya menunjukkan sejumlah bukti yang mendukung hipotesis bahwa OPEC merupakan produsen dominan pada periode 1981 dan 1983. Spilimbergo (2001) menggunakan kerangka dinamik dan menolak hipotesis bahwa OPEC merupakan kartel selama periode 1983-1991. Green (1988) mengemukakan, tapi tanpa menunjukkan ukuran-ukuran secara statistik yang signifikan, bahwa OPEC berperilaku sebagai swing producer hanya pada siklus musim tertentu saja, yaitu meningkatkan produksi selama bulan-bulan musim dingin ketika permintaan sedang meningkat dan mengurangi produksi selama sisa bulan yang lain.

Studi Dahl dan Yucel (1991) mengenai OPEC, menunjukkan bahwa hubungan jangka panjang dapat diterapkan dengan melakukan perilaku pembagian pasar (kartel). Mereka melakukan uji kointegrasi pada: i) produksi individual dari tiap anggota dan output total OPEC, dan ii) produksi individual dari tiap anggota dan sisa output OPEC. Untuk kasus pertama, hanya Algeria yang menunjukkan perilaku sebagai kartel dan untuk kasus kedua, mereka tidak menemukan hubungan pasangan yang berkointegrasi. Secara keseluruhan mereka menolak perilaku kooperatif dari negara-negara anggota OPEC. Sementara itu, studi yang dilakukan oleh Gulen (1996) yang mengembangkan penelitian Dahl dan Yucel (1991) dengan membagi penelitian dalam periode-periode tertentu, menyatakan bahwa OPEC berperilaku sebagaimana kartel pada periode 1980-an untuk mempertahankan harga. Sementara itu, OPEC hanya mengambil keuntungan dari kondisi pasar pada tahun 1970-an dan tidak mengendalikan jumlah produksinya. Almoguera dan Hererra (2005) menemukan bahwa ada sejumlah periode di mana harga minyak menjadi tinggi karena kolusi di antara anggota-anggota OPEC, namun secara keseluruhan OPEC tidak mampu secara efektif meningkatkan harga di atas tingkat harga kompetitif.

\subsection{Uji Kausalitas Granger}

Secara umum untuk menguji hubungan kausal antara 2 variabel, uji standar Granger (1969) digunakan dalam banyak literatur yang relevan. Uji ini menyatakan bahwa jika nilai masa lalu dari variabel $Y$ secara signifikan memberikan pengaruh peramalan pada nilai variabel lainnya; $X_{t+1}$, maka $Y$ dikatakan Granger cause $X$ dan begitu pula sebaliknya. Pengujian tersebut didasarkan pada regresi berikut ini:

$$
\begin{aligned}
& Y_{t}=\beta_{0}+\sum_{k=1}^{M} \beta_{\mathrm{k}} Y_{t-k}+\sum_{l=1}^{N} \alpha_{l} X_{t-l}+u_{t} \\
& X_{t}=\gamma_{0}+\sum_{k=1}^{M} \gamma_{\mathrm{k}} X_{t-k}+\sum_{l=1}^{N} \delta_{l} Y_{t-l}+v_{t}
\end{aligned}
$$

Di mana $Y_{t}$ dan $X_{t}$ adalah variabel yang akan diuji, dan $u_{t}$ dan $v_{t}$ adalah white noise errors yang tidak berkorelasi satu sama lain, dan $t$ menunjukkan periode waktu dan $k$ an $I$ adalah jumlah lag. Hipotesis nol $\left(\mathrm{H}_{0}\right)$ adalah $\alpha_{l}=\delta_{l}=0$ untuk seluruh / dengan hipotesis alternatif $\left(\mathrm{H}_{\mathrm{A}}\right)$ adalah

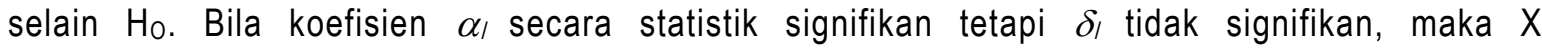
menyebabkan $Y$ dan demikian sebaliknya. Tetapi bila $\alpha_{l}$ dan $\delta$ l keduanya signifikan maka terdapat kausalitas dua arah.

Dalam perkembangan analisis time series telah disarankan sejumlah perbaikan dalam uji standar Granger. Salah satunya disebabkan karena kausalitas Granger sangat sensitif pada 
pemilihan lag length. Jika lag length yang dipilih lebih kecil dari lag length yang sebenarnya, maka dapat menjadi bias. Jika lag length yang dipilih lebih besar, maka lag yang tidak relevan pada suatu persamaan dapat menyebabkan estimasi yang tidak efisien. Untuk mengatasi permasalahan ini, Hsiao (1981) mengembangkan suatu metode autoregresif yang sistematis untuk memilih lag length yang optimal untuk tiap variabel suatu persamaan. Metode ini menggabungkan kausalitas Granger dengan Akaike's Final Prediction Error (FPE).

\subsection{Prosedur Toda dan Yamamoto (1995)}

Prosedur yang dikembangkan oleh Toda dan Yamamoto (1995) mengijinkan untuk menggunakan standar statistik inferensi dalam model VAR yang terintegrasi dan kemungkinan variabel-variabelnya berkointegrasi. Seperti yang dinyatakan oleh Toda dan Yamamoto (1995) keuntungan menggunakan prosedur ini adalah bahwa untuk menguji hipotesis ekonomi yang kita inginkan (dalam kasus kita, uji kausalitas Granger dalam kerangka VAR) tidak perlu untuk melakukan uji tahap awal variabel untuk integrasi dan syarat-syarat kointegrasi di mana hal tersebut menghindari kemungkinan uji tahap awal yang bias.

Prosedur ini didasarkan pada estimasi pada model augmented VAR $(k+d m a x)$, di mana $k$ adalah lag length dalam sistem semula dan dmax adalah orde maksimal dari variabel yang terintegrasi dalam penelitian. Toda dan Yamamoto (1995) menyarankan untuk menggunakan uji Wald untuk restriksi nol dari koefisien autoregresif $k$ yang pertama pada variabel yang akan diuji dalam hipotesis nol bahwa tidak ada Granger cause pada variabel dependen pada masing-masing persamaan VAR. Tabel 1 menunjukkan penelitian sebelumnya yang menggunakan metode Toda dan Yamamoto (1995) dalam berbagai macam penelitian.

Tabel 1.

Penelitian Empiris Sebelumnya dengan Metode Toda \& Yamamoto (1995)

\begin{tabular}{|c|c|c|}
\hline No. & Penelitian & Variabel yang diamati \\
\hline 1. & Shan (1999) & $\begin{array}{l}\text { ungan antara imigrasi dan pengangguran di } \\
\text { tralia dan Selandia Baru }\end{array}$ \\
\hline 2. & Shan \& W & Hubungan antara Perdagangan dan Pariwisata di China \\
\hline 3. & Hatemi \& Irandousti (2002) & Hubungan antara kurs dengan stock price di Swedia \\
\hline 4. & Awokuse \& Yang (2002) & $\begin{array}{l}\text { Hubungan antara harga komoditas, fed fund rates, } \\
\text { inflasi, money stock dan produksi sektor industri di } \\
\text { Amerika Serikat }\end{array}$ \\
\hline 5. & Awokuse (2003) & Uji hipotesis export-led growth di Kanada \\
\hline 6. & Seabra \& Flach (2004) & $\begin{array}{l}\text { Hubungan antara penanaman modal asing dan profit } \\
\text { outflow di Brazil }\end{array}$ \\
\hline 7. & Siliverstovs \& Herzer (2005) & Uji hipotesis export-led growth di Chili \\
\hline 8. & Chowdhury \& Mavrotas (2005) & $\begin{array}{l}\text { Hubungan antara penanaman modal asing dan } \\
\text { pertumbuhan di Chili, Malaysia dan Thailand }\end{array}$ \\
\hline 9. & $\begin{array}{l}\text { Bhattacharya \& Mukherjee } \\
\text { (2005) }\end{array}$ & $\begin{array}{l}\text { Hubungan antara pasar modal dan kurs; cadangan } \\
\text { valuta asing dan nilai trade balance di India }\end{array}$ \\
\hline
\end{tabular}

\section{METODA PENELITIAN}

Data yang digunakan adalah data kuartalan dari 1974:QI - 2005:QIV. Data berasal dari US Government Energy Information Administration. Penelitian ini menggunakan 3 variabel, yaitu: (1) Harga minyak dunia (PRICE) rata-rata tiga bulan, merupakan data harga minyak U.S. Crude Oil Imported Acquisition Cost by Refiners (US Dolar per Barel) yang telah dideflasikan dengan 
GDP deflator, $2 Q$ tahun 2005. (2) Produksi minyak mentah OPEC (OPEC) dan (3) produksi minyak mentah Non-OPEC (NONOPEC), keduanya dengan satuan ribuan barel per hari.

Pengujian kausalitas Granger terbagi dalam empat periode; 1974:QI - 2005:QIV (seluruh sampel), 1974:QI - 1981:QIV (setelah oil shock pertama), 1982:QI - 1997:QII (sebelum krisis moneter), dan 1997:QIII - 2005:QIV (sesudah krisis moneter). Pembedaan periode waktu untuk melihat apakah ada perbedaan hasil antara satu periode dengan periode lain. Model yang akan diuji adalah sebagai berikut:

LNPRICE $_{t}=\beta_{0}+\sum_{i=1}^{k+d} \beta_{\mathrm{i}}$ LNPRICE $_{t-i}+\sum_{i=1}^{k+d} \alpha_{i}$ LNOPEC $_{t-i}+u_{1 t}$
LNOPEC $_{t}=\gamma_{0}+\sum_{i=1}^{k+d} \gamma_{\mathrm{i}}$ LNOPEC $_{t-i}+\sum_{i=1}^{k+d} \delta_{i}$ LNPRICE $_{t-i}+u_{2 t}$
LNPRICE $_{t}=\theta_{0}+\sum_{i=1}^{k+d} \theta_{\mathrm{i}}$ LNPRICE $_{t-i}+\sum_{i=1}^{k+d} \rho_{i} \operatorname{LNNONOPEC}_{t-i}+v_{1 t}$

LNNONOPEC $_{t}=\xi_{0}+\sum_{i=1}^{k+d} \xi_{\mathrm{i}}$ LNNONOPEC $_{t-i}+\sum_{i=1}^{k+d} \phi_{i}$ LNPRICE $_{t-i}+v_{2 t}$

Di mana LNPRICE, LNOPEC dan LNNONOPEC masing-masing adalah bentuk logaritma dari harga minyak mentah riil, produksi OPEC dan produksi Non-OPEC, $k$ adalah orde lag yang optimal dari model VAR, $d$ adalah orde maksimal dari variabel yang terintegrasi dalam sistem persamaan dan $u_{1}, u_{2}, v_{1}, v_{2}$ adalah error terms yang diasumsikan white noise.

\section{HASIL ANALISIS DAN PEMBAHASAN}

Untuk melakukan analisis kausalitas Granger dalam model augmented VAR ( $k+d m a x)$, pertama; perlu menentukan orde lag dari model VAR awal. Kedua; orde maksimal dari variabel yang terintegrasi, dmax. Untuk menentukan lag yang optimal, banyak penelitian yang menggunakan metode yang dikembangkan oleh Hsiao (1981), yaitu Final Prediction Error (FPE). Penelitian ini selain menggunakan FPE juga akan menggunakan kriteria pemilihan yang lain seperti sequential modified likelihood ratio LR test (LR), Akaike Information Criterion (AIC), the Schwarz Criterion (SC), dan the Hannan-Quinn (HQ) information criterion - untuk memastikan bahwa lag length yang dipilih sudah merupakan yang terbaik ${ }^{1}$. Tabel 2 menunjukkan lag length yang dipilih untuk masing-masing periode.

Tabel 2.

Penentuan Lag Length Terbaik dengan Model VAR

\begin{tabular}{lcl}
\hline \multicolumn{1}{c}{ Periode } & Lag & \multicolumn{1}{c}{ Keterangan } \\
\hline 1974:QI - 2005:QIV & 5 & Lag optimal dari 3 kriteria (LR, FPE, AIC) \\
1974:QI - 1981:QIV & 1 & Lag optimal dari 3 kriteria (LR, SC, HQ) \\
1982:QI - 1997:QII & 5 & Lag optimal dari 3 kriteria (LR, FPE, AIC) \\
1997:QIII - 2005:QIV & 1 & Lag optimal dari 3 kriteria (LR, SC, HQ) \\
\hline
\end{tabular}

1 Penentuan lag yang terbaik pada studi ini juga telah memenenuhi kriteria bebas autokorelasi, bebas heteroskedastisitas dan memenuhi asumsi normalitas. 
Pada tahap selanjutnya, kita akan menentukan orde maksimal dari variabel yang terintegrasi, dmax. Pada umumnya untuk menentukan derajat integrasi, dapat menggunakan metode Augmented Dickey-Fuller (ADF) dan Phillip-Perron (PP). Namun permasalahannya adalah, uji unit root yang konvensional seperti ADF dan PP tidak dapat diterapkan pada kasus pasar minyak mentah (Perron, 1989; Zivot dan Andrews, 1992; Gulen 1996). Perron (1989) ${ }^{2}$ menunjukkan bahwa, secara analisis maupun empiris, adanya structural breaks pada time series yang stasioner memungkinkan adanya kesalahan pada unit root yang terlihat. Uji unit root kehilangan kekuatannya ketika diterapkan pada data yang memiliki trend breaks (Gulen, 1996). Oleh karena itu, untuk menghindari kemungkinan bias dalam menentukan tingkat integrasi dan juga kointegrasi pada data time series, maka ditetapkan orde integrasi seperti yang dihipotesiskan oleh Gulen (1996), yaitu terintegrasi pada derajat 1, I(1). Dengan demikian, dalam analisis ini ditetapkan $d \max =1$.

Setelah lag length yang optimal untuk masing-masing periode didapatkan dan dmax juga telah ditentukan, maka hasil uji kausalitas Granger untuk dapat dilihat pada Tabel 3 berikut ini.

Tabel 3.

Hasil Kausalitas Granger dengan Prosedur Toda dan Yamamoto (1995)

\begin{tabular}{|c|c|c|}
\hline Arah Hubungan & $p$-value & Kesimpulan \\
\hline \multicolumn{3}{|c|}{ Seluruh Sampel 1974:QI - 2005:QIV $(k=5, d=1)$} \\
\hline In PRICE $\rightarrow$ In OPEC & 0.15230 & Ho diterima \\
\hline In OPEC $\rightarrow$ In PRICE & 0.30080 & Ho diterima \\
\hline In PRICE $\rightarrow$ In NONOPEC & 0.46571 & Ho diterima \\
\hline In NONOPEC $\rightarrow$ In & 0.81411 & Ho diterima \\
\hline \multicolumn{3}{|c|}{ 1974:QI - 1981:QIV $(k=1, d=1)$} \\
\hline In PRICE & 0.01421 & $\mathrm{H}_{\mathrm{O}}$ ditolak** \\
\hline In OPEC & 0.55434 & $\mathrm{H}_{\circ}$ diterima \\
\hline In NONOPEC & 0.08641 & $\mathrm{H}_{\mathrm{O}}$ ditolak* \\
\hline$C \rightarrow$ In PRICE & 0.08112 & $\mathrm{H}_{\mathrm{O}}$ ditolak* \\
\hline \multicolumn{3}{|c|}{ 1982:QI - 1997:QII $(k=5, d=1)$} \\
\hline In PRICE $\rightarrow$ In OPEC & 0.19066 & $\mathrm{H}_{0}$ diterima \\
\hline In OPEC $\rightarrow$ In PRICE & 0.58700 & Ho diterima \\
\hline In PRICE $\rightarrow$ In NONOPEC & 0.11804 & Ho diterima \\
\hline In NONOPEC $\rightarrow$ In PRICE & 0.84564 & Ho diterima \\
\hline
\end{tabular}

2 Penelitian Perron (1989) ini kemudian dikembangkan lagi oleh Zivot \& Andrews (1992). 


\begin{tabular}{|c|c|c|}
\hline Arah Hubungan & $p$-value & Kesimpulan \\
\hline \multicolumn{3}{|c|}{ 1997:QIII - 2005:QIV $(k=1, d=1)$} \\
\hline In PRICE $\rightarrow$ In OPEC & 0.00128 & $\mathrm{H}_{\mathrm{O}}$ ditolak ${ }^{* * *}$ \\
\hline In OPEC $\rightarrow$ In PRICE & 0.75976 & $\mathrm{H}_{0}$ diterima \\
\hline In PRICE $\rightarrow$ In NONOPEC & 0.32529 & Ho diterima \\
\hline In NONOPEC $\rightarrow$ In PRICE & 0.08866 & $\mathrm{H}_{0}$ ditolak$^{*}$ \\
\hline $\begin{array}{rr}\text { ngan : *** } & \text { signifikan } p \\
* * & \text { signifikan } p \\
* & \text { signifikan p }\end{array}$ & $\begin{array}{l}\text { keperca } \\
\text { keperca } \\
\text { t keperca }\end{array}$ & \\
\hline
\end{tabular}

Untuk periode seluruh sampel (1974:QI - 2005:QIV) tidak terbukti adanya hubungan kausalitas antara harga dengan produksi OPEC serta antara harga dengan produksi Non-OPEC yang ditunjukkan dengan rendahnya $p$-value untuk seluruh persamaan. Sedangkan pada periode setelah oil shock yang pertama (1974:QI - 1981:QIV), terdapat hubungan kausalitas satu arah, yaitu harga mempengaruhi produksi minyak OPEC dengan $p$-value sebesar 0,01421 . Sementara itu di sisi lain, ternyata ada hubungan kausalitas dua arah antara harga minyak mentah dengan produksi Non-OPEC dengan signifikansi sebesar 10 persen, di mana harga minyak mempengaruhi produksi Non-OPEC dan produksi Non-OPEC mempengaruhi harga minyak mentah. Namun yang perlu dicatat adalah kemampuan Non-OPEC dalam mempengaruhi harga hanya mungkin terjadi bila Non-OPEC sebagai suatu organisasi, di mana seluruh produsen Non-OPEC bersepakat untuk mengurangi atau menambah produksi mereka, tidak diartikan bahwa tiap negara produsen minyak Non-OPEC mampu mempengaruhi harga minyak. Penelitian Gulen (1996) bahkan menunjukkan bahwa Arab Saudi sekalipun, sebagai produsen minyak terbesar di dunia, tidak mampu mempengaruhi harga minyak.

Sementara itu, pada periode 1982:QI - 1997:QII (sebelum krisis moneter), juga tidak ditemukan bukti-bukti adanya adanya hubungan kausalitas antara harga dengan produksi OPEC dan juga antara harga dengan produksi Non-OPEC yang ditunjukkan dengan rendahnya $p$-value untuk seluruh persamaan. Untuk periode 1997:QIII - 2005:QIV terdapat hubungan kausalitas satu arah, yaitu harga mempengaruhi produksi minyak OPEC dengan signifikansi sebesar 1 persen dan ditemukan juga bahwa terdapat kausalitas satu arah antara harga minyak mentah dengan produksi Non-OPEC dengan signifikansi sebesar 10 persen, di mana produksi Non-OPEC mempengaruhi harga minyak mentah. Seperti halnya hasil pada periode setelah oil shock yang pertama (1974:QI - 1981:QIV), kemampuan Non-OPEC dalam mempengaruhi harga hanya mungkin terjadi bila NonOPEC diasumsikan sebagai suatu organisasi, dan bukan sebagai kemampuan tiap negara NonOPEC. Mengapa produksi Non-OPEC mampu mempengaruhi harga minyak mentah dunia? Barangkali Gambar 3 mampu memberikan jawaban. Jumlah produksi total dari Non-OPEC selalu di atas 50 persen dari seluruh total produksi minyak mentah dunia, sehingga Non-OPEC memiliki kemampuan untuk mempengaruhi harga.

Kegagalan OPEC dalam mempengaruhi harga minyak mentah dapat dilihat pada Gambar 4. Ketika harga minyak mengalami tren menurun setelah bulan Februari 1981 karena adanya peningkatan produksi oleh negara-negara Non-OPEC, OPEC meresponnya dengan mengurangi produksi. Namun pengurangan produksi OPEC ternyata tidak mampu mempertahankan harga dari kejatuhannya sehingga harga terus jatuh pada titik terendah pada harga sekitar $\$ 10$ pada Juli 1986. 


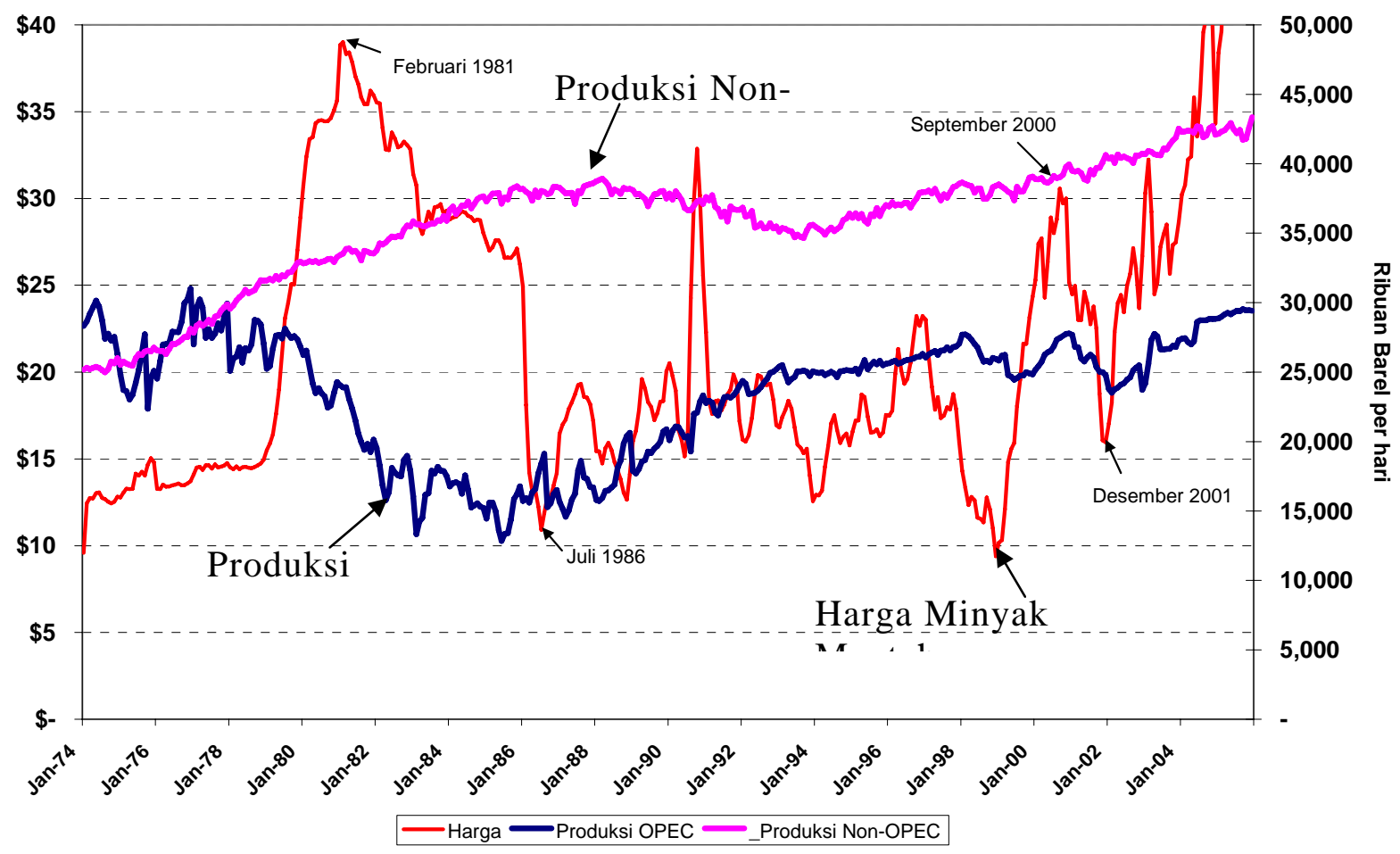

Gambar 4.

Perkembangan Produksi Minyak Mentah OPEC, Non-OPEC dan Harga Minyak Mentah Dunia Nominal, Januari 1974 - Desember 2005

Ketika harga mulai jatuh setelah bulan September 2000, OPEC meresponnya dengan mengurangi produksi minyak mentah, karena 2 kemungkinan; pertama, tidak ingin mengalami kerugian dengan mempertahankan produksi yang ada karena harga kurang menguntungkan; kedua, berusaha mempengaruhi harga. Namun jelas usaha mengurangi produksi untuk mempengaruhi harga mengalami kegagalan karena harga terus mengalami penurunan sampai Desember 2001. Di saat yang sama, produksi Non-OPEC tidak mengalami penurunan. Setelah Desember 2001, harga meningkat dan produksi OPEC juga ikut meningkat.

Kesimpulan yang bisa diambil adalah OPEC secara organisasi gagal mempengaruhi harga minyak mentah dunia. OPEC bertindak seperti halnya perusahaan, yaitu hanya mengambil keuntungan dari kondisi pasar. Penelitian ini pada akhirnya mendukung penelitian Alhajji dan Huettner (2000a; 2000b) yang juga menolak hipotesis kartel bagi OPEC. Sejarah menunjukkan bahwa faktor politik lebih banyak ikut serta dalam mempengaruhi harga minyak mentah dibandingkan variabel-variabel ekonomi.

\section{PENUTUP}

Dengan menggunakan pendekatan yang dikembangkan oleh Toda dan Yamamoto (1995), penelitian ini menunjukkan bahwa hipotesis kartel tidak terbukti bagi OPEC. Dalam periodeperiode sampel penelitian yang dipilih, tidak ditemukan bukti-bukti bahwa OPEC mampu mempengaruhi harga minyak mentah dunia. Tujuan pembentukan OPEC untuk menstabilkan harga minyak mentah dunia ternyata mengalami hambatan, salah satunya berasal dari para anggotanya sendiri. 
Dalam penelitiannya Perron (1989) menunjukkan bahwa, secara analisis maupun empiris, adanya structural breaks pada time series yang stasioner memungkinkan adanya kesalahan pada unit root yang terlihat. Penggunaan analisis ekonometrika sederhana dalam menganalisis pasar minyak mentah dunia sangat mungkin menimbulkan bias pada hasil-hasilnya. Salah satu upaya yang penulis lakukan adalah dengan melakukan modifikasi data dari data bulanan menjadi data kuartalan.

\section{DAFTAR PUSTAKA}

Alhajji, A.F. dan D. Huettner, (2000a), "OPEC And World Curde Oil Markets Fom 1973 To 1994: Cartel, Oligopoly, Or Competitive?", The Energy Journal, 21, pp. 31-60.

Alhajji, A.F. dan D. Huettner, (2000b), "OPEC and Other Commodity Cartels: A Comparison", Energy Policy, 28, pp. 1151-1164.

Almoguera, P.A. dan A.M. Herrera, (2005), "A Study of OPEC Cartel Stability", Working Paper Michigan State University.

Awokuse, Titus O., (2003), "Is The Export-Led Growth Hypothesis Valid For Canada?", Canadian Journal of Economics, Volume 36 pp. 126, March.

Awokuse, Titus O. dan J. Yang, (2002), "The Informational Role Of Commodity Prices In Formulating Monetary Policy: A Reexamination", FREC Research Reports, the University of Delaware.

Bhattacharya, B dan J. Mukherjee, (2005), "Causal Relationship Between Stock Market And Exchange Rate, Foreign Exchange Reserves And Value Of Trade Balance: A Case Study For India", 7th Annual Conference on Money and Finance in the Indian Economy, New Delhi, India.

Chowdhury, A., dan G. Mavrotas, (2005), "FDI and Growth: A Causal Relationship", Research Paper No. 2005/25, World Institute for Development Economic Research, Helsinki.

Dahl, C. dan M. Yucel, (1991), "Testing Alternative Hypotheses of Oil Producer Behavior", The Energy Journal, 12 (4), pp. 117-138.

Granger, C.W.J., (1969), "Investigating Causal Relations by Econometric Models and Cross Spectral Models". Econometrica 37, pp. 424-438.

Granger, C. W. J. dan P. Newbold, (1974), "Spurious Regressions in Econometrics". Journal of Econometrics, 2, pp. 111-120.

Green, D., (1988), "The World Oil Market: An Examination Using Small Scale Models", The Energy Journal, 9 (3), pp. 61-76.

Griffin, J.M., (1985), "OPEC Behavior: A Test of Alternative Hypotheses", American Economic Review, 75(5), pp. 954-963.

Griffin, J.M., dan W.S. Nielson, (1994), "The 1985-1986 Oil Price Collapse and Afterwards: What Does Game Theory Add?", Economic Inquiry, 32 (4), pp. 543-561. 
Gulen, S.G., (1996), "Is OPEC A Cartel? Evidence From Cointegration and Causality Tests", The Energy Journal, 17 (2), pp. 43-57.

Hatemi, A.J., dan M. Irandousti, (2002), "On the Causality Between Exchange Rates and Stock Prices: A Note", Bulletin of Economic Research, Volume 54, pp. 197

Hsiao, C., (1981), "Autoregressive Modelling and Money-Income Causality Detection". Journal of Monetary Economics, pp. 85-106.

Kaufmann, R.K, S. Dees, P. Karadeloglou, dan M. Sanchez, (2004), "Does OPEC Matter? An Econometric Analysis of Oil Prices". The Energy Journal 25 (4), pp. 67-90.

Kaufmann, R.K, A. Bradford, L.H. Belanger, J. Mclaughlin, dan Y. Miki (2005), "Determinants of OPEC Production: Implications For OPEC Behavior", Center for Energy \& Environmental Studies. Boston.

Jones, C.T., (1990), "OPEC Behavior Under Falling Prices: Implications For Cartel Stability", The Energy Journal, 11 (3), pp. 117-129.

Loderer, C., (1985). "A Test of The OPEC Cartel Hypothesis: 1974-1983". The Journal of Finance, 40 (3), pp. 991-1006.

Perron, P., (1989), "The Great Crash, the Oil Price Shock, and the Unit Root Hypothesis". Econometrica, 5, pp. 1361-1401.

Polasky, S., (1992), "Do Oil Producers Act As "Oil" Gopolists?" Journal or Envirnmental Economics and Management, 23 (3), pp. 216-247.

Ramcharran, H., (2002), "Oil Production Responses to Price Changes: an Empirical Application of the Competitive Model to OPEC and Non-OPEC Countries", Energy Economics 24, pp. 97106.

Shan, J., (1999), "Immigration and Unemployment: New Evidence From Australia and New Zealand", International Review of Applied Economics, Volume 13, pp. 253-260

Shan, J. dan K. Wilson, (2001), "Causality between Trade and Tourism: Empirical Evidence from China", Applied Economics Letters, April, Volume 8, pp. 279-283.

Siliverstovs, Boriss dan D. Herzer, (2005), "Export-led Growth Hypothesis: Evidence For Chile", Discussion Paper, Ibero-America Institute for Economic Research (IAI), George-AugustUniversität Göttingen.

Seabra, Fernando dan L. Flach, (2004), "Foreign Direct Investment and Profit Outflows: A Causality Analysis for the Brazilian Economy", Economics Bulletin, Vol. 6, No. 1 pp. 1-15

Smith, J.L., (2005), "Inscrutable OPEC? Behavioral Tests of The Cartel Hypothesis". The Energy Journal, 26 (1), pp. 51-82. 
KINERJA, Volume 10, No.2, Th. 2006: Hal. 89-102

Spilimbergo, A., (2001), "Testing the Hypothesis of Collusive Behavior among OPEC Members". Energy Economics, Vol. 23, pp. 339-353.

Toda, H.Y. dan T. Yamamoto, (1995), "Statistical Inference in Vector Autoregressions With Possibly Integrated Processes". Journal of Econometrics (66), pp. 225-250.

Zivot, E. dan D.W.K Andrews, (1992), "Further Evidence on the Great Crash, the Oil-Price Shock, and the Unit-Root Hypothesis". Journal of Business and Economic Statistics. Volume 10 (3), pp. 251-270. 